\title{
Intonation and its interfaces in Sardinian polar questions
}

\author{
María del Mar Vanrell ${ }^{1}$, Francesc Ballone ${ }^{2}$, Carlo Schirru³ and Pilar Prieto ${ }^{4}$ \\ ${ }^{1}$ Freie Universität Berlin, ${ }^{2}$ Institut d'Estudis Catalans, ${ }^{3}$ Università degli Studi di Sassari, ${ }^{4}$ ICREA-Universitat Pompeu Fabra \\ mariadelmar.vanrell@fu-berlin.de, francesco.ballone@libero.it, ska@uniss.it, pilar.prieto@upf.edu
}

\begin{abstract}
Submitted: 7 de febrero de 2014. Accepted: 7 de abril de 2014. Available on line: 20 de abril de 2015
Citation / Cómo citar este artículo: Vanrell, M. M., Francesc, B., Schirru, C., Prieto, P. (2014). Intonation and its interfaces in sardinian polar questions. Loquens, 1(2), e014. doi: http://dx.doi.org/10.3989/loquens.2014.014

ABSTRACT: In this paper we investigate the interplay between lexicon, syntax, intonation and pragmatics in Sardinian polar questions. To this end, a production study was designed to elicit polar questions with different bias and polarity conditions by means of the Discourse Completion Task Methodology. The resulting data were then prosodically and syntactically annotated using Praat. The results can be summarized as follows. Regarding lexico-syntactic markers, the particle $a$ functions as a mitigator or politeness marker, whereas constituent fronting and negation correspond to positive and negative polarity respectively. In addition, two main intonational patterns can be distinguished: the ${ }_{i} \mathrm{H}+\mathrm{L} * \mathrm{~L} \%$ pattern, which expresses "lack of bias", and the ${ }_{i} \mathrm{H}^{*}+\mathrm{L}$ L- pattern, which conveys the speaker bias towards the proposition.
\end{abstract}

Keywords: Sardinian; polar questions; intonation

RESUMEN: La entonación y sus interfaces en las preguntas absolutas del sardo.- Este artículo investiga la interacción entre sintaxis, entonación, pragmática y partículas interrogativas en las preguntas absolutas del sardo. Con tal propósito, se diseñó un experimento de producción mediante la metodología de la Tarea de Compleción del Discurso que permite obtener interrogativas absolutas en diferentes condiciones de sesgo y polaridad. Los datos se analizaron prosódica y sintácticamente mediante el programa Praat. Los resultados se pueden resumir como sigue: en relación con los marcadores léxico-sintácticos, la partícula a funciona como un mitigador o marcador de cortesía, mientras que la anteposición de constituyentes y la negación se corresponden con la polaridad positiva y negativa respectivamente. En cuanto a la prosodia, se distinguen dos patrones entonativos principales: el patrón $¡ \mathrm{H}+\mathrm{L} * \mathrm{~L} \%$, que expresa "ausencia de sesgo", y el patrón ${ }_{i} \mathrm{H}^{*}+\mathrm{L} \mathrm{L} \%$, que codifica el sesgo del hablante hacia la proposición.

Palabras clave: sardo; preguntas absolutas; entonación

\section{INTRODUCTION}

Yes-no questions are those questions whose answer is either "yes" or "no" (see (1) for a Sardinian example). The fact that they are restricted to just two possible answers explains why they are also called "polar questions". They contrast with wh-questions, which are questions asking about the word or phrase the wh-word replaces, as in (2) for Sardinian. The mechanisms used to mark polar questions in natural languages are diverse. According to Dryer (2013), they can be marked by means of (a) a question particle added to a declarative sentence to indicate that it is a question, as in (3) for Maybrat (Dol, 1999); (b) distinct interrogative verbal morphology (see (4) for Tunica; Haas, 1940); (c) a combination of both question particle and interrogative verbal morphology, as in (5) for Pirahã (Everett, 1986); (d) different word order (see (6) for German); (e) the absence of morphemes used in declaratives (see (7) for Zayse; Hayward, 1990); or (f) a distinct intonation pattern. This cross-linguistic marking of polar questions is mainly restricted to neutral questions, i.e., questions for which the speaker has no particular expectations about the answer. However, we know that the intention behind the act of asking can be more than just a mechanism to solicit information, but may instead reflect a need to confirm assumptions, formulate an offer, express surprise, etc.
(1) Mandarinu, a che nd'at? (Sardinian) tangerine Q CL.LOC CL.PART 3SG-have 'Do you have tangerines?'
(2) Itte naras? (Sardinian) what 2sG-say 'What do you say/mean?' 
(3) ana m-amo Kumurkek a (Maybrat)

3PL 3-go Kumurkek Q

'Are they going to Kumurkek?'

(4) lo'ta wi-wa'nă-n (Tunica)

run 2sG-want-Q

'Do you want to run?'

(5) a. xií bait-áo-p-Ii "híx (Pirahã)

cloth wash-TELIC-IMPF-PROX Q

'Are you going to wash clothes?'

b. xísi ib-áo-p-óxóí

3.animal hit.ARROW-TELIC-IMPF-Q

'Did you arrow fish?'

(6) a. Der Lehrer trinkt das Wasser (German)

the teacher drink-3sg the water

'The teacher is drinking the water'

b. Trinkt der Lehrer das Wasser?

drink-3SG the teacher the water

'Is the teacher drinking the water?'

(7) a. hamá-tte-ten (Zayse)

'I will go'

b. háma-ten

'Will I go?'

In recent years a considerable amount of research has been devoted to the interface between semanticspragmatics and prosody in polar questions for different languages dealing with information structure and/or degree of certainty about the truth value of the proposition (Grice \& Savino 1997, 2003, for Italian; Haan, 2001, for Dutch; Kügler, 2003, for German; Santos \& Mata, 2008, for Portuguese; Vanrell, Mascaró, Torres-Tamarit, \& Prieto, 2013, for Catalan); speaker bias (Asher \& Reese, 2007; Hwang \& Ito, 2014, for Japanese; Armstrong, in press, for Spanish); information source (Hara \& Kawahara, 2012, for Japanese; Vanrell, Armstrong, \& Prieto, 2014, for Catalan) and/or requests (Álvarez \& Blondet, 2003; Estrella-Santos, 2007; Orozco Vaca, 2008, 2010, for Spanish; Astruc, Vanrell, \& Prieto, in press; Nadeu $\&$ Prieto, 2011, for Catalan); and incredulity or disbelief (Lee, 2010, for Spanish; Crespo-Sendra, 2011, for Catalan). These studies tend to concentrate on the intonational patterns used to convey specific meanings but they often disregard the lexico-syntactic structure itself or how these tonal events interact with lexicon and syntax. Additionally, as pointed out by Armstrong (in press) most of these works use coarse-grained distinctions like information-seeking questions or unbiased questions vs. confirmation-seeking questions or biased questions, which do not always "allow us to capture different points on the epistemic gradient that might be candidates for intonational encoding". In this paper we will make an attempt to encompass the aforementioned aspects and reconcile both the lexico-syntactic and the prosodic perspective.
Romance languages are often described as marking questions by means of a distinct intonational pattern. This may be attributable to the fact that most Romance languages (with the exception of French) are pro-drop, lack an auxiliary verb (compared to some other European languages) and present a more free word order. In fact, a variety of question-marking strategies can be seen in different Romance languages including word order (Rigau, 2002, for Catalan; Brandi \& Cordin, 1989; Poletto, 1991; Renzi \& Vanelli, 1982; Rizzi, 1986, for Friulian and Rhaeto-Romance and Gallo-Italic languages; Vanrell \& FernándezSoriano, 2013, 2014, for different Catalan and Spanish varieties); question particles (Prieto \& Rigau, 2007, for Catalan; Fossat, 2006; Karenova, 2006; Pusch, 2000, for Gascon Occitan); and interrogative verbal morphology (Lusini, 2013, p. 38; Manzini \& Savoia, 2005, p. 377, for the dialect of Cortemilia, Northern Italy). Sardinian is a Romance language that marks questions using three of these strategies, namely, question particles, word order and intonation. ${ }^{1}$ Sardinian polar questions can be headed by particles such as a (e.g., $\boldsymbol{A}$ benis a jocare chin mecus? 'Are you coming to play with me?'; Jones, 1993), can also present constituent fronting (Mandicattu as? 'Have you eaten?', Ello, inoche ses? 'Are you here?', Mortu in s'ispidale est? 'Did he die in the hospital?'; see Remberger, 2010) and can be characterized by different intonational patterns ${ }_{i} \mathrm{H}+\mathrm{L} * \mathrm{~L} \%,{ }_{i} \mathrm{H}^{*}+\mathrm{L} \mathrm{L} \%$ in the Sard ToBI system; see Contini, 1984; Schirru, 1982, 1992a, 1992b; and Vanrell et al., in press). Regarding constituent fronting, it has been characterized as a common marker in polar questions without being part of a question-formation process (Jones, 1993) and as a strategy for marking positive focus often with an emphatic value (i.e., the speaker expects it to be true that $p$; Remberger, 2010). On the other hand, the particle $a$ has been described as being predominantly (but not exclusively) used in questions which are to be interpreted as requests, invitations and offers (Jones, 1993). For Jones (1993), the meaning of particle $a$ is that of a politeness marker indicating the speaker's willingness to accept denial or acceptance. Yet for Remberger (2010), there is no clear semantic difference between focus fronting and the marker $a$ : "yes/no questions with focus fronting as well as those marked by $a$ (which is clearly encoding positive polarity) will be treated as marked for positive polarity" (2010, p. 571). Floricic (2009) discusses the possibility that the particle $a$ is a clitic, since it can appear as part of a clitic cluster with the partitive nde (e.g., Frutta, a nde cheres? 'Fruit, do you want any?'; 2009, p. 132) and presents a series of distributional restrictions in that the particle $a$ precedes the proposition that is questioned and this causes extra-sentential elements like vocatives or thematic constituents to be left out of the scope of the particle $a$ (see (8)-(10)). However, ultimately Floricic (2009) discards this hypothesis by providing counterexamples like that

\footnotetext{
${ }^{1}$ Sardinian shares this set of three question-marking strategies with French: question particles (Est-ce que tu as vu mon frère? 'Did you see my brother?'), word order (As-tu vu mon frère? 'Did you see my brother?'), and intonation (Tu as vu mon frère? 'Did you see my brother?').
} 
seen in (11), in which the particle $a$ bears the main stress of the sentence, and finally concludes that the function of the particle $a$ is that of assigning "focal value to the content in its scope" (2009, p. 146). As for intonation, the $j \mathrm{H}+\mathrm{L} * \mathrm{~L} \%$ pattern tends to be related to information-seeking yes-no questions or questions with unspecified evidential/epistemic bias (Vanrell, Ballone, Schirru, \& Prieto, 2014; Vanrell et al., in press), whereas the pattern ${ }_{i} \mathrm{H}^{*}+\mathrm{L} \mathrm{L} \%$ is related to confirmation questions, including echo yes-no questions (Vanrell et al., in press) or biased yes-no questions in general (Vanrell, Ballone, et al., 2014). Interestingly, the falling pattern generally appears with yes-no questions introduced by the particle $a$ (e.g., A times? 'Are you scared?') or yes-no questions with no specific lexical/syntactic marker (e.g., A s'abba? 'To the water?'). By contrast, yes-no questions presenting constituent fronting (e.g., Bidu l'as? 'Have you seen him?') tend to be characterized by a risingfalling intonation pattern (Contini, 1984).

(8) A mi podes agiuare?

Q CL.DO.1SG 2sG.can help

'Could you help me?'

(9) a. Anne', a nos cumbidas?

Anne', Q CL.DO.1PL 2sG.invite

'Anne', are you inviting us?'

b. *A Anne', nos cumbidas?

(10) a. Un'àtteru caffè, a mi lu battis?

another coffee Q CL.IO.1SG CL.DO.3MSG 2sG.bring

'Could you bring me another coffee?'

b. *A un'àtteru caffè, mi lu battis?

(11) - $\boldsymbol{A}$ mi podes agiuare?

Q CL.DO.1sG 2sG.can help

'Could you help me?'

-E a? Non lu podes fàghere tue?

and Q? NEG CL.DO.3MSG 2sG.can do you

'And why? Can't you do it yourself?'

In this paper we seek to refine the analysis presented in Vanrell et al. (in press) for the ${ }_{i} \mathrm{H}+\mathrm{L}^{*} \mathrm{~L} \%$ and ${ }_{i} \mathrm{H}^{*}+\mathrm{L}$ $\mathrm{L} \%$ tonal events associated with unbiased and biased polar questions respectively. We also aim to assess whether there exists a one-to-one correspondence between lexicosyntactic and intonational structure as is defended in Contini (1984) and Vanrell, Ballone, et al. (2014). According to these studies, the prosodic structure of a polar question is determined by its lexico-syntactic structure. Finally, we hope to shed some light on the specific meanings related to the linguistic markers found in Sardinian polar questions. Specifically, since question particles have been shown to mark not only questions but also different types of speaker bias in languages like Japanese (Hara, 2013; Sudo, 2013), we want to determine whether there is some sort of relationship between the different linguistic markers found in Sardinian polar questions and speaker bias.

\section{METHODOLOGY}

\subsection{Participants}

The participants in our production experiment were 11 Sardinian women, ${ }^{2}$ aged between 47 and 73, coming from three locales of the Logudorese area (in the centre and north of the island): İttiri ${ }^{3}$ (three speakers), Puttumajore (four speakers) and Ottieri (four speakers). All three locales are in the province of Tàttari, and they have populations of approximately 9,000, 3,000 and 11,000, respectively (see map in Figure 1). Sardinian was the dominant language of all interviewees and they were naïve to the objective of the experiment.

Figure 1: Locales from which data analyzed in the study were collected.

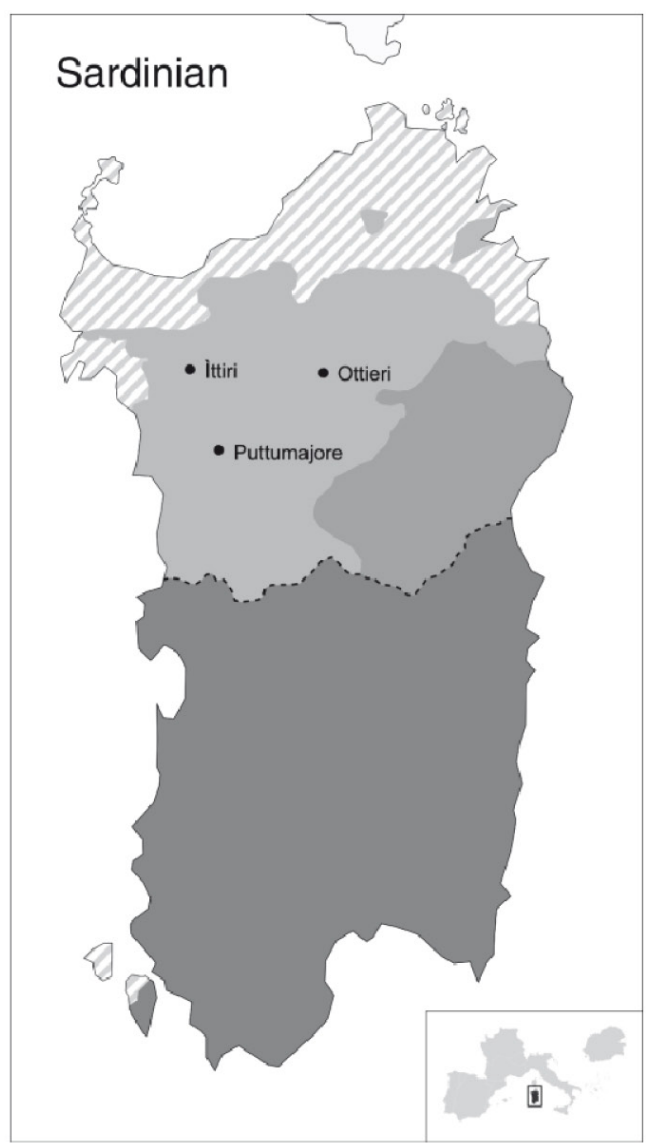

Dialects

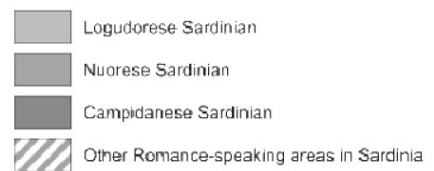

\footnotetext{
${ }^{2}$ The justification for using only women is that women tend to exhibit a wider pitch range, which allows for the creation of smoother intonation contours.

${ }^{3}$ Throughout the paper the Sardinian toponyms, rather than the italicized place names, will be used.
} 


\subsection{Materials}

The corpus analyzed in this paper was obtained by means of the Discourse Completion Task methodology or DCT (Billmyer \& Varghese, 2000; Blum-Kulka, Haus, \& Kasper, 1989; Félix-Brasdefer, 2010). It is a tool used especially in second language acquisition research to elicit specific speech acts. It consists of a series of discourse prompts "based on everyday situations which are designed to elicit a specific speech act by requiring informants to complete a turn of a dialogue for each item" (Barron, 2003). One of the most important aspects of this method is that the researcher can manipulate the contextual variables of the discourse prompts to see how language changes in accordance with changing factors. Basing ourselves on previous work on speaker bias and interrogatives (Armstrong, in press; Asher \& Reese, 2007; Büring \& Gunlogson, 2000; Ito \& Oshima, in press; Ladd, 1981; Romero \& Han, 2002; Sudo, 2013), we created a set of situations which contained three different bias conditions (neutral, epistemic and evidential) with positive and negative polarity (conveying the speaker bias towards either a positive or negative answer). Examples of discourse prompts designed to elicit each of the three bias conditions are offered in (12)-(14) below.

(12) Neutral condition: Has unu pagu de tusciu e, tott'in una, faeddende cun una de carrela, incumintzas a intèndere unu iscrafinzu a ula. Pregunta·li si at una caramella.

'You have a bit of a cough and suddenly, while you're talking to a neighbor, you feel a sore throat coming on. Ask her if she has a cough drop.'

(13) Positive epistemic condition: Una de carrela t'at nadu chi fut andende a sa butica, e t'at preguntadu si cherias calchi cosa dae in ie. Tue nd'as aprofitta$d u$, e l'as nadu de ti comporare sas caramellas pro sa ula, chi ti dolet meda. Cando la bides torrende, $l i$ preguntas si t'at battidu sas caramellas.

'A neighbor of yours told you that she was going to the pharmacy and asked whether you needed anything from there. Happy to take advantage of her offer, you asked her to buy you some cough drops because you have a sore throat. Now you see her coming back from the pharmacy. Ask her if she's got the cough drops for you.'

(14) Positive evidential condition: In carrela intopas un'amiga chi non bidias dae meda. Li preguntas comente istat sa fiza, e issa ti narat chi est semper istracca, ca andat semper a s'iscola chitto, a sas otto de manzanu, battor dies a sa chida. Pro cussu tue li preguntas si sa fiza est diventada professora.

'In the street you run into a friend who you haven't seen for a long time. You ask her how her adult daughter is doing and she tells you that her daughter is always tired because she starts school at 8 A.M. four days a week. For that reason you ask her whether her daughter has become a teacher.'
The neutral situations used as discourse prompts were not biased towards either a positive or a negative response. In the epistemic situations, by contrast, the speaker's bias was based on beliefs or expectations or what s/ he would assume to be a norm (Sudo, 2013). In (13), for example, the speaker "expects" that her friend is bringing the cough drops, since she previously requested it. The evidential situations were based on evidence available in the immediate context of the conversation (Sudo, 2013). In the specific situation in (14) the speaker has just inferred from what was said by their interlocutor that the interlocutor's daughter may have become a teacher and therefore asks for confirmation. The full questionnaire contained ten items and we elicited a total of 110 utterances $(5$ bias/polarity conditions $\mathrm{x} \quad 2$ items $\mathrm{x} \quad 11$ participants).

\subsection{Procedure}

The interviews were conducted by the first and second authors of the paper (the second author is a native speaker of Logudorese Sardinian) in October 2011 (İttiri) and March 2012 (Puttumajore and Ottieri). Each questionnaire was adapted to the specific lexical characteristics of each locale by the second author of this research. The different items of the questionnaire were read aloud in random order to the participants by the Sardinian interviewer and speakers were then asked to respond appropriately to the situation as spontaneously as possible. Sentences were recorded only once, but when a problem arose with a specific situation (such as speech disfluencies or difficulty in understanding the pragmatic situation), it was left to the end of the session and then presented a second time to the participants. Generally the situations did not present problems of elicitation.

All the speakers were recorded in a relaxed atmosphere in their homes or public spaces in the village (e.g., a school). Participants in İttiri were recorded on a MSI U100 Wind Notebook laptop equipped with a Realtek HD sound card and PC 131 Micro-Headphones using GoldWave version 5.14, whereas participants in Puttumajore and Ottieri were recorded using a Marantz Professional PMD660 digital recorder and Rode NTG-2 microphone. The whole task lasted approximately 30 minutes.

\subsection{Analyses}

The target utterances obtained through the DCT method were isolated using a Praat (v. 5.3.83) script and then annotated for the following fields: (1) orthographic transcription (including not just the interrogative sentence, but the whole production); (2) lexico-syntactic markers such as particle $a$, fronted constituents or negation; (3) prosodic transcription of nuclear configuration according to the ToBI system as applied to Sardinian (Sard ToBI, Vanrell et al., in press); and (4) additional lexical markers such as de abberu or beru est (conveying incredulity). Table 1 
Table 1: Summary of the different prosodic units found in Sardinian polar questions.

\begin{tabular}{|l|l|l|l|}
\hline $\begin{array}{c}\text { Sard_ToBI } \\
\text { label }\end{array}$ & $\begin{array}{c}\text { Nuclear configuration, } \\
\text { schematic } \\
\text { representation }\end{array}$ & Description \\
\hline $\mathrm{L}+\mathrm{H}^{*} \mathrm{~L} \%{ }^{4}$ & $\begin{array}{l}\text { The pitch accent is phonetically realized as a rise starting at the beginning of the } \\
\text { accented syllable and ending at the end of the accented syllable. The final boundary } \\
\text { tone is low. This nuclear configuration is uncommon in Sardinian, appearing only in } \\
\text { exclamative sentences and some polar questions. }\end{array}$ \\
\hline$i \mathrm{H}+\mathrm{L}^{*} \mathrm{~L} \%$ & $\begin{array}{l}\text { The pitch accent is realized as a fall with a preaccentual extra-high tone and the peak } \\
\text { aligned at the beginning of the accented syllable. The final boundary tone is also } \\
\text { low. This nuclear contour is common in polar questions and echo questions. }\end{array}$ \\
\hline $\mathrm{i} \mathrm{H}^{*}+\mathrm{L} \mathrm{L} \%$ & $\begin{array}{l}\text { The pitch accent is realized as a rise-fall with an extra high peak aligned broadly at } \\
\text { the midpoint of the vowel. The boundary tone is low. This nuclear configuration is } \\
\text { attested in polar and wh- questions. }\end{array}$ & \\
\hline
\end{tabular}

offers a schematic representation of the different nuclear configurations found in the data.

Since the process of orthographic normalization of Sardinian is still in progress and some inconsistencies can be found, we based the transcription of our data on the following general criteria:

(a) Respect for the principle of invariance. Many Sardinian words may be pronounced in different ways, according to dialectal and contextual factors, such as the numeral tres 'three': tre[ze] but tre [s] canes 'three dogs' or tre[1] canes, or tre [x:] anes and so on. However, the orthographic form will always be rendered as tres.

(b) Conservation of some etymological consonants. In Sardinian some etymological consonants such as the final $-t$ in the third person plural of the present indicative are deleted in the Logudorese variety. We also find a process of lenition that affects simple plosives and voiceless fricatives derived from Latin at the level of the word and between word boundaries. In the specific case of voiced intervocalic plosives, this process may lead to deletion (e.g., tatza de binu> [tatsae'inu] 'a glass of wine') in both Logudorese and Campidanese va- rieties (Jones, 1988). These deletions will not be reflected in the orthography.

(c) Accentuation. Considering that the vast majority of Sardinian words are paroxytones (Vanrell et al., in press), many scholars have found it most practical to write a graphic accent only on words with final and antepenultimate stress, and this is the criterion followed here. However, neither the official proposal for a common Sardinian language (LSC or Limba Sarda Comuna 'Common Sardinian Language'; Regione Autonoma della Sardegna, 2006) nor the proposal for Campidanese Sardinian (Regione Autonoma della Sardegna, 2006; Comitao Scientificu po sa Norma Campidanesa de su Sardu Standard, 2009) follow this criterion in words like ['fidzu] 'son', transcribing it instead with a graphic accent (figiu) in spite of its being a paroxytone. We will avoid this inconsistency by transcribing figiu ['fidzu] with no graphic accent.

(d) Geminated consonants. Scholars are often divided on the issue of the graphic transcription of certain intervocalic consonants (/t/, /p/, /f/ and others). Both the official guidelines for LSC (Regione Autonoma della Sardegna, 2006) and Comitao Scientificu po sa Norma Campidanesa de su Sardu

\footnotetext{
${ }^{4}$ In some of the examples illustrated in the paper, the boundary tone L- will be used instead of L\%. As stated in the previous paragraph, only the nuclear configuration of each utterance was annotated. In cases of constituent fronting (as in the examples seen in Figures 8 and 9), the nuclear accent falls on the rightmost element of the fronted constituent (i.e., battidas 'brought.FEM.PL' in Figure 8 and battidu 'brought. MASC.SG' in Figure 9). Our data (as well as the intuition of two of the co-authors of this paper, native speakers of Sardinian) reveal a level of juncture between the fronted constituent and the following element that is looser than that which exists between words, but tighter than that existing between independent tonal units. This allowed us to posit an intermediate prosodic constituent between the Prosodic Word (PW) and the Intonational Phrase (IP) (see Vanrell et al., in press). The type of tonal event associated with the right edge of the IP in Sardinian can be low or mid. Thus, in the present examples we have a low boundary tone followed by the - symbol, which indicates that the L tone is associated with the right edge of the intermediate phrase or fronted constituent. The L- boundary tone is also found at the right edge of the core sentence in polar questions with a right-dislocated element (see Figure 5, in which the constituent tumattas 'tomatoes' is right-dislocated).
} 
Standard (2009) suggest not using double graphemes in those cases where lengthening is not contrastive. However, some scholars claim that using double graphemes would be consistent with the intuitive perception of these consonants as geminated. We followed somewhat more phonetic criteria and transcribed the word for 'milk' as latte 'milk', 'affection' as affettu and so on.

These criteria were used not solely in the orthographic transcription of the data collected for this research but also to transcribe the Sardinian productions taken from other sources and the names of the locales where data analyzed in this study was collected. In doing so, we intended to provide a standardized and orthographic transcription to facilitate the reading and comprehension of Sardinian utterances.

\section{RESULTS}

The final corpus consists of $112^{5}$ sentences (İttiri $n=$ 30; Ottieri $n=42$; Puttumajore $n=40$ ).

We will first examine the general results and then have a look at the data after separating it into the three different bias conditions (neutral in Section a, epistemic condition in Section $b$ and evidential condition in Section c).

Figure 2 shows the incidence of each lexico-syntactic strategy (particle $a$, constituent fronting, negation, neutral word order $^{6}$ and other) and each intonation pattern $\left({ }_{i} \mathrm{H}+\mathrm{L} * \mathrm{~L} \%,{ }_{i} \mathrm{H}^{*}+\mathrm{L} \mathrm{L} \%, \mathrm{~L}+\mathrm{H}^{*} \mathrm{~L} \%\right.$ and other $)$ in the general data. As can be seen, the preferred strategy used by the Logudorese speakers is the combination of constituent fronting with the $\mathrm{iH}^{*}+\mathrm{L} \mathrm{L} \%$ pattern (e.g., Ebbe', cus-

Figure 2: Lexico-syntactic and intonational strategies used with polar questions.
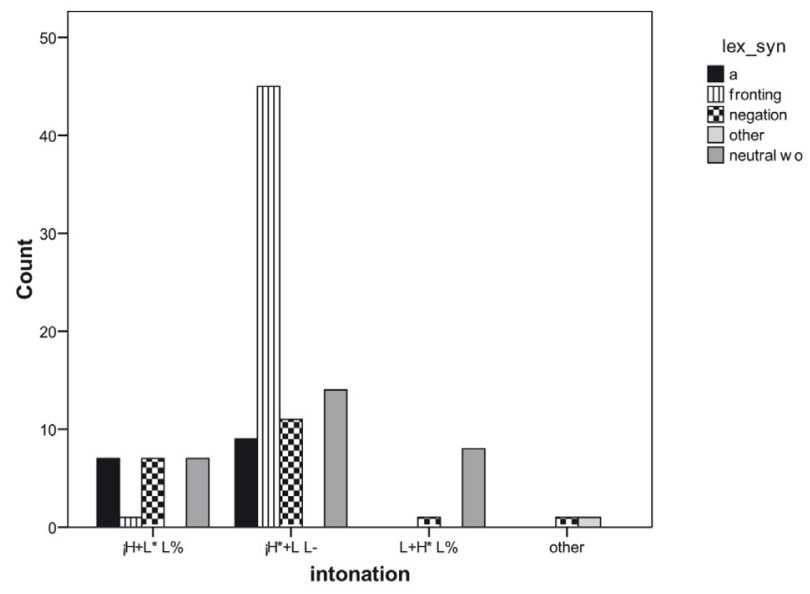

su liberu, battidu mi l'as? 'So, this book, have you brought it to me?'). It appears in 45 instances, which represents $34 \%$ of the data. At some distance from this pattern, we find the same intonational pattern but with neutral word order (e.g., Ti nde ses ammentada, a mi comporare sas caramellas in farmacia? 'Have you remembered it, to buy the cough drops at the pharmacy?'), which is used in 14 out of 112 cases. Less frequent strategies are the use of the $i \mathrm{H}^{*}+\mathrm{L} \mathrm{L} \%$ pattern with negation (e.g., Tando, frùtture e birdura, no nd bendides pius? 'So, fruit and vegetables, you don't sell them anymore?') or with the particle $a$ (e.g., A la tenes, una caramella? 'Do you have it, a cough drop?').

The examples labeled as displaying "other" lexico-syntactic strategies correspond to syntactic structures less common in the literature such as disjunctive polar questions (e.g., A bi nd'at o non bi nd'at, de bagna? 'Is there tomato sauce or is there no tomato sauce?') or questions with external adverbials of the type how come (cando mai in Sardinian; e.g., Ma cando mai ti as mandigadu tottas sas caramellas? 'How come you have eaten all the candies?').

\subsection{Neutral condition}

In the neutral condition, the context was unbiased (see (12)). The speakers were merely told to ask, out of the blue, for specific information, e.g., whether the interlocutor had a cough drop or whether $\mathrm{s} /$ he had tomatoes. The preferred lexico-syntactic strategy in the neutral condition was the use of the particle $a$ (e.g., $A$ nde tenes, tumattas? 'Do you have any, tomatoes?'), but we observe variation in the rate of intonational pattern (see Figure 3). Thus, 12 out of 23 cases were produced with the $¡ \mathrm{H}^{*}+\mathrm{L}$

Figure 3: Lexico-syntactic and intonational strategies used with polar questions in the neutral bias condition.

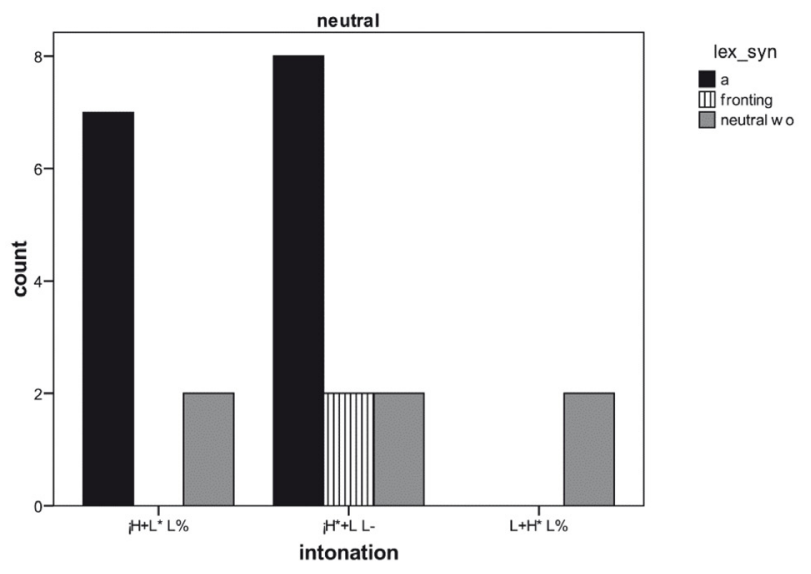

\footnotetext{
${ }^{5}$ The number 110 was given above. The extra items were produced when two subjects were asked to repeat one of the elicitation tasks because it was felt that the first productions were inadequate. After it was verified that both initial and repeated productions were adequate, they were both included in the final corpus.

${ }^{6}$ Neutral word order refers to the sentences in which a declarative order (with no constituent fronting) is found and also sentences with right/left dislocation. The category neutral word order excludes both the presence of the particle $a$ and negation.
} 
$\mathrm{L} \%$ pattern, whereas 9 out of 23 utterances were associated with the $¡ \mathrm{H}+\mathrm{L} * \mathrm{~L} \%$ pattern.

Since our data are nominal and do not fulfill the normality assumption, we used non-parametric tests as statistical analyses. A set of Wilcoxon matched pairs signed rank tests was applied with INTONATION and LEXICO-SYNTACTIC STRATEGY as dependent variables and BIAS-POLARITY (5 levels) as the independent variable. In our results, the neutral Bias-Polarity condition differed from the positive epistemic $(T=22.5, p<.05, r=-.18)$ BIAs-PoLARITY condition with respect to INTONATION and also from the negative epistemic $(T=50, p<.05, r=-.18)$ and positive evidential $(T=36, p<.05, r=-.18)$ Bias-Polarity conditions with respect to LEXICO-SYNTACTIC STRATEGY.

Figures 4 and 5 show examples of the two preferred patterns found in neutral contexts. Figure 4 illustrates the ${ }_{\mathrm{H}} \mathrm{H}+\mathrm{L} * \mathrm{~L} \%$ pattern, whereas Figure 5 shows the $\mathrm{iH}^{*}+\mathrm{L}$ $\mathrm{L} \%$ pattern.

\subsection{Epistemic condition}

Following Sudo (2013), in the epistemic condition the speakers were presented with pragmatic contexts in which the speaker's bias would be based on beliefs or expectations or what s/he took to be a norm (see (13) for an example of a positive epistemic condition). Figures 6 and 7 show the results for the positive (Figure 6) and negative (Figure 7) epistemic conditions. It will be noted that the preferred strategy for both positive and negative epistemic conditions was the combination of the pattern $i \mathrm{H}^{*}+\mathrm{L}$ $\mathrm{L} \%$ with constituent fronting (17 out of 23 utterances in the positive epistemic condition and 15 out of 26 in the negative epistemic condition) (e.g., Custu liberu, dae munitzipiu, battidu mi l'as? 'The book from the city council, have you brought it to me?'). Interestingly, a more residual strategy in both positive and negative epistemic conditions is the ${ }_{i} \mathrm{H}^{*}+\mathrm{L} \mathrm{L} \%$ pattern but with neutral word order

Figure 4: Waveform and $f_{0}$ contour of the utterance Una caramella, a l'as? ('A cough drop, do you have one?').

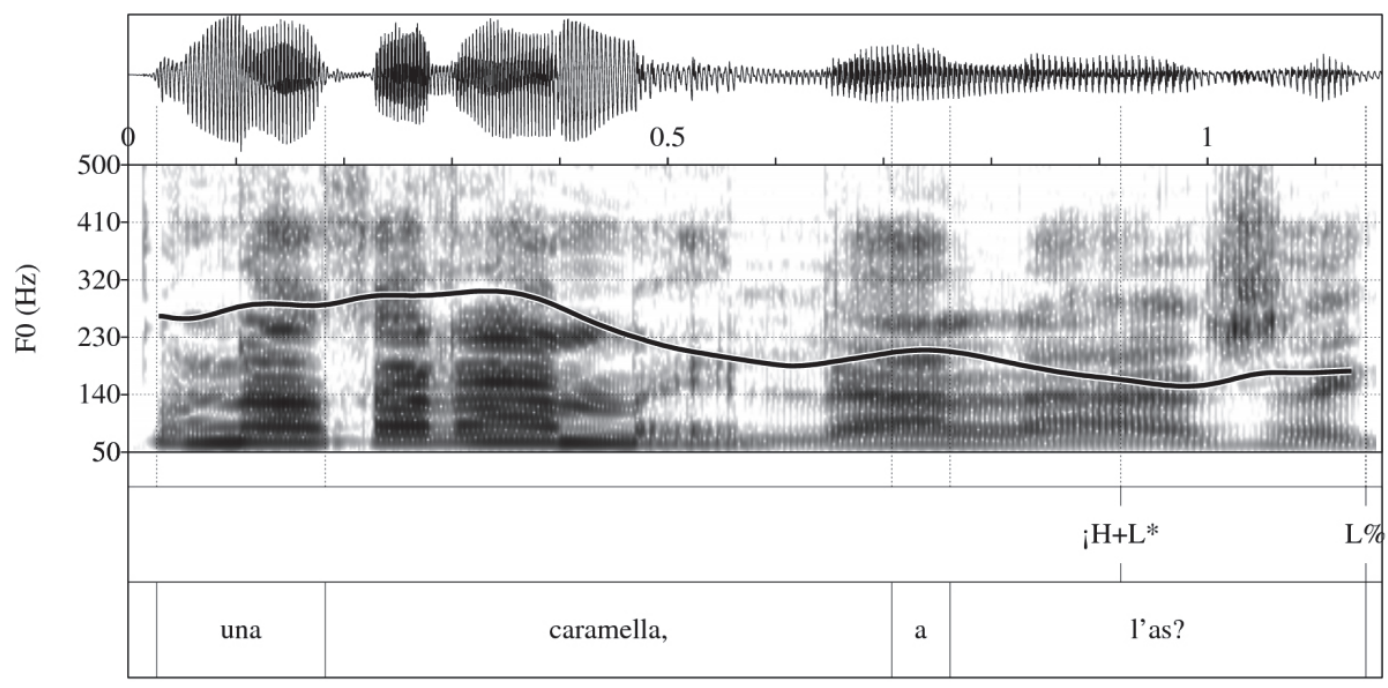

Figure 5: Waveform and $f_{0}$ contour of the utterance $\boldsymbol{A}$ nde tenes, tumattas? ('Do you have any, tomatoes?').

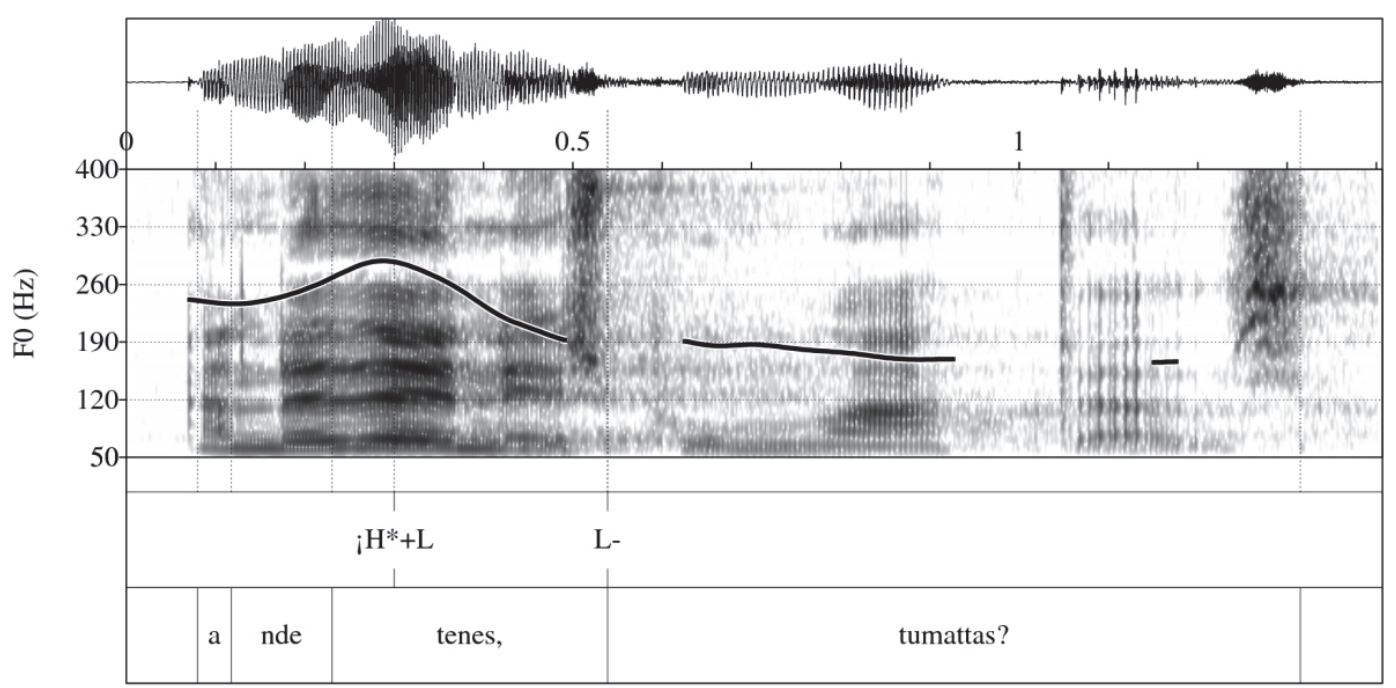


Figure 6: Lexico-syntactic and intonational strategies used with polar questions in positive epistemic bias condition.

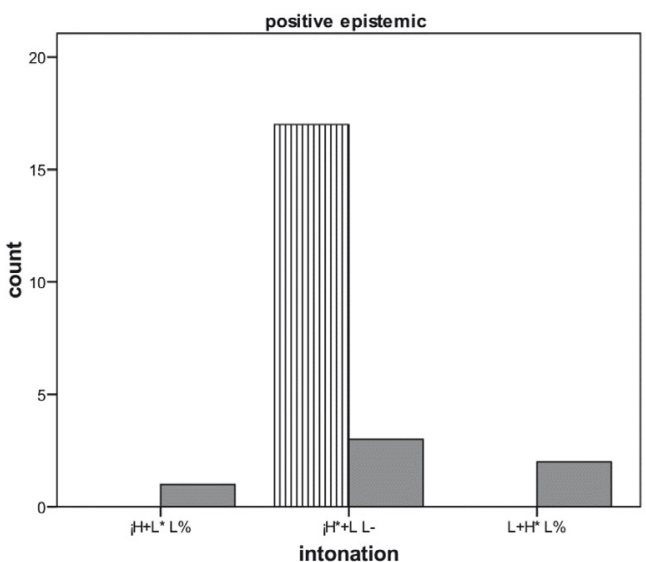

Figure 7: Lexico-syntactic and intonational strategies used with polar questions in negative epistemic bias condition.

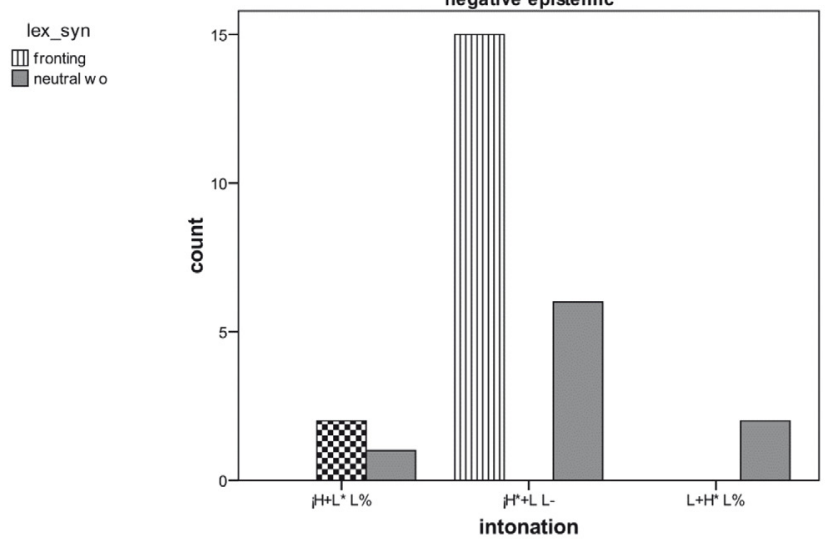

lex syn

狊 fronting

Negation

Figure 8: Waveform and $f_{0}$ contour of the utterance Battidas mi las as, sas caramellas? ('Have you brought them to me, the cough drops?').

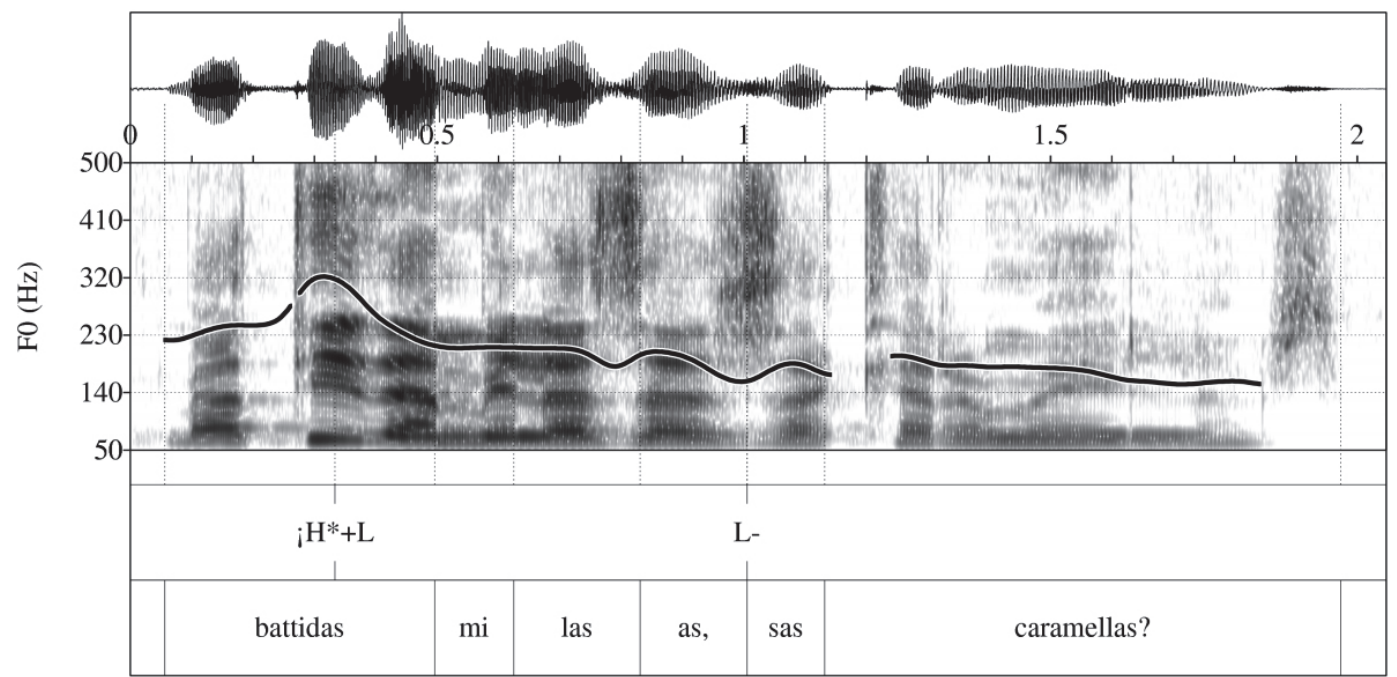

Figure 9: Waveform and $f_{0}$ contour of the utterance Mi l'as battidu, su liberu? ('Have you brought it to me, the book?').

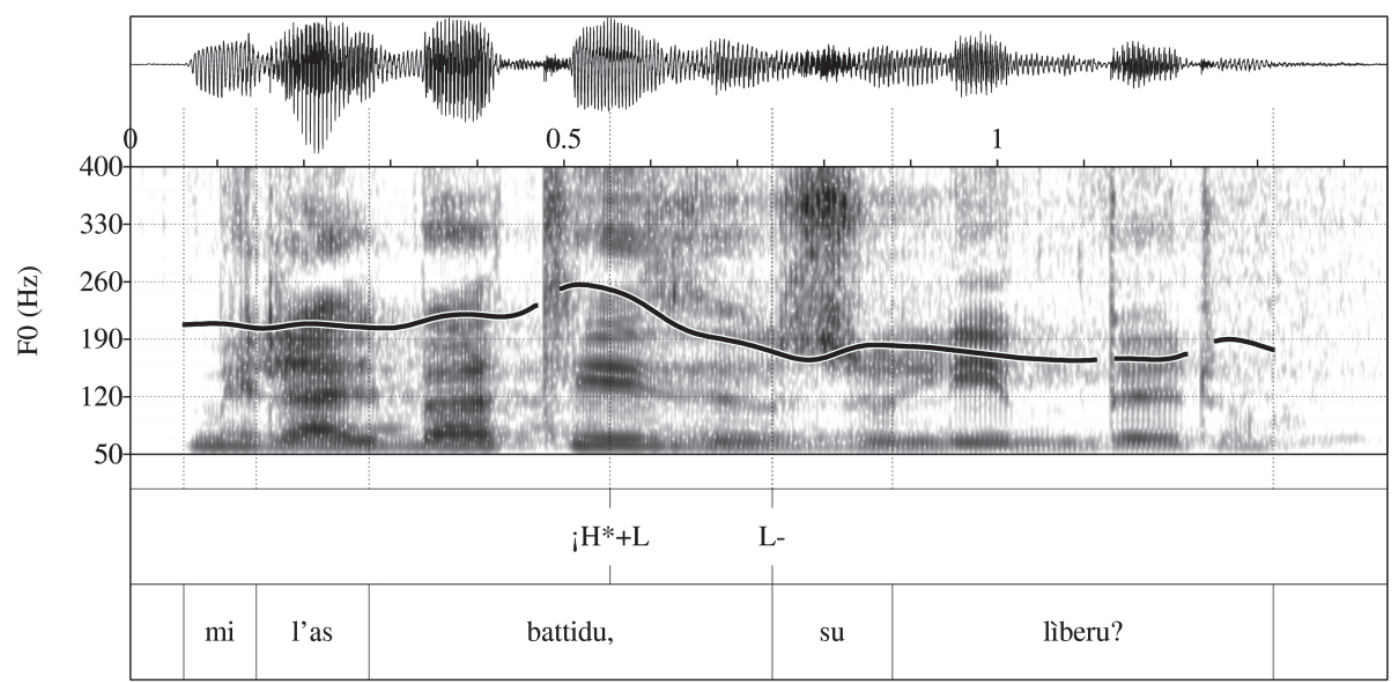


(e.g., Mi l'as battidu, su liberu? 'Have you brought it to me, the book?').

The results of a series of Wilcoxon matched pairs signed rank tests revealed significant differences only between the positive epistemic condition and the neutral condition $(T=$ 22.50, $p<.05, r=-.18$ ) for INTONATION as well as between the negative epistemic condition and the neutral condition ( $T$ $=50, p<.05, r=-.18$ ) for LEXICO-SYNTACTIC STRATEGY.

Figure 8 shows an example of a polar question with constituent fronting and the ${ }_{i} \mathrm{H}^{*}+\mathrm{L} \mathrm{L} \%$ intonational pattern produced in the positive epistemic condition. Figure 9 illustrates a polar question with neutral word order and the ${ }_{i} \mathrm{H}^{*}+\mathrm{L} \mathrm{L} \%$ pattern produced in the negative epistemic condition.

\subsection{Evidential condition}

Again following Sudo (2013), the evidential condition was based on evidence available in the context of

Figure 10: Lexico-syntactic and intonational strategies used with polar questions in the positive evidential condition.

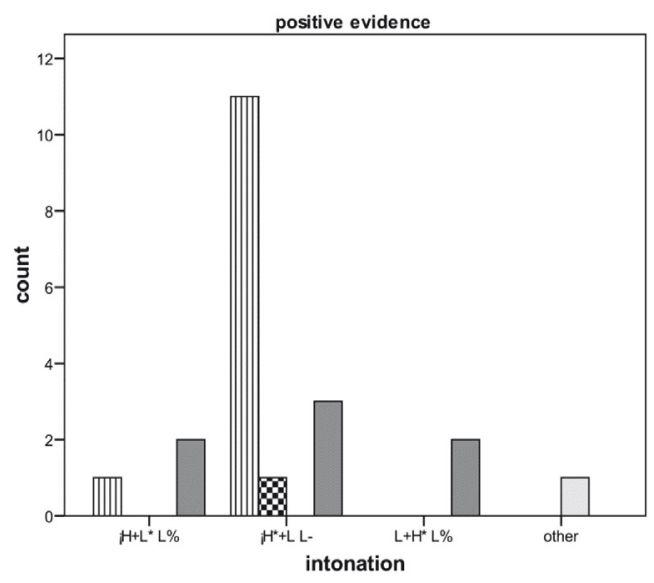

the immediate conversation. This contextual evidence could be in agreement with $p$ (positive evidence, Figure 10 ) or contradictory to $p$ (negative evidence, Figure 11). Figure 10 shows a clear preference for the ${ }_{i} \mathrm{H}^{*}+\mathrm{L} \mathrm{L} \%$ intonational pattern produced on a polar question with constituent fronting (e.g., Ma in pintzione ses andada? 'Have you retired?'). This pattern appears in 11 out of 21 utterances. By contrast, in Figure 11 we observe a very different pattern which consists of a preference either for negation and the $\mathrm{i}^{*}+\mathrm{L} \mathrm{L} \%$ pattern (e.g., Ma no nde bendides pius, de frùtture e de birdura, como? 'You will not sell them anymore, any fruit and vegetables?') or for negation with the ${ }_{i} \mathrm{H}+\mathrm{L} * \mathrm{~L} \%$ pattern (e.g., Non ti l'ant a rinnovare, su cuntrattu? 'They will not renew it for you, the contract?'). 10/19 polar questions in the negative evidential condition were produced with the former pattern and $5 / 19$ with the latter. It is interesting to see that a quarter of the data corresponding to the negative evidential condition was produced with negation in concomi-

Figure 11: Lexico-syntactic and intonational strategies used with polar questions in the negative evidential condition.
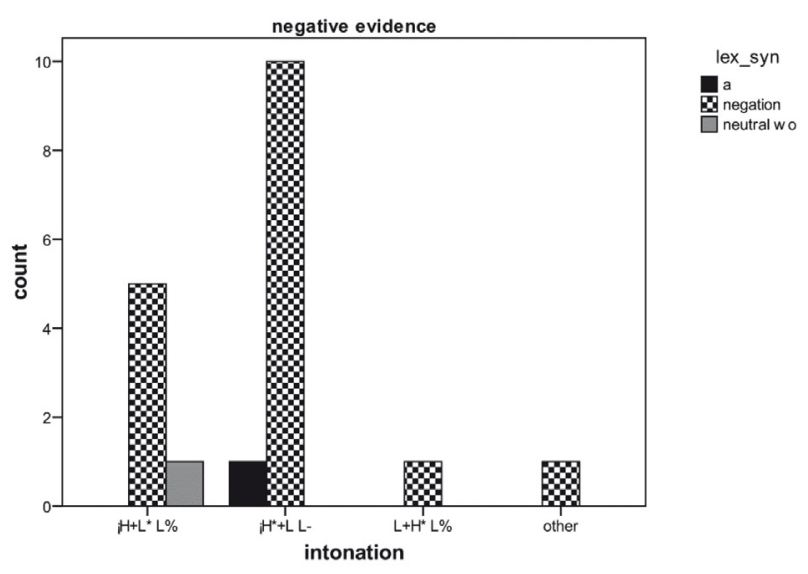

Figure 12: Waveform and $f_{0}$ contour of the utterance Ma in pintzione ses andada? ('Have you retired?').

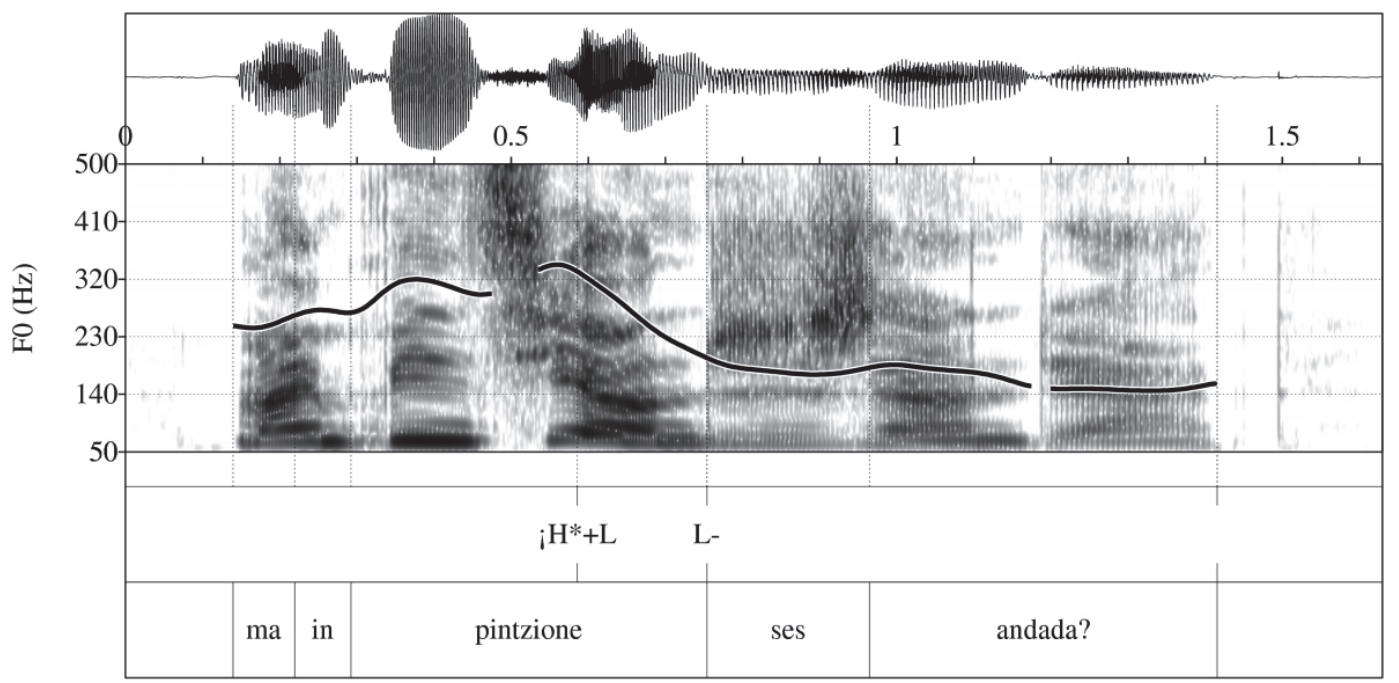


Figure 13: Waveform and $f_{0}$ contour of the utterance Tando, frùtture e birdura, no nde bendides pius? ('So, fruit and vegetables, you aren't going to sell them anymore?').

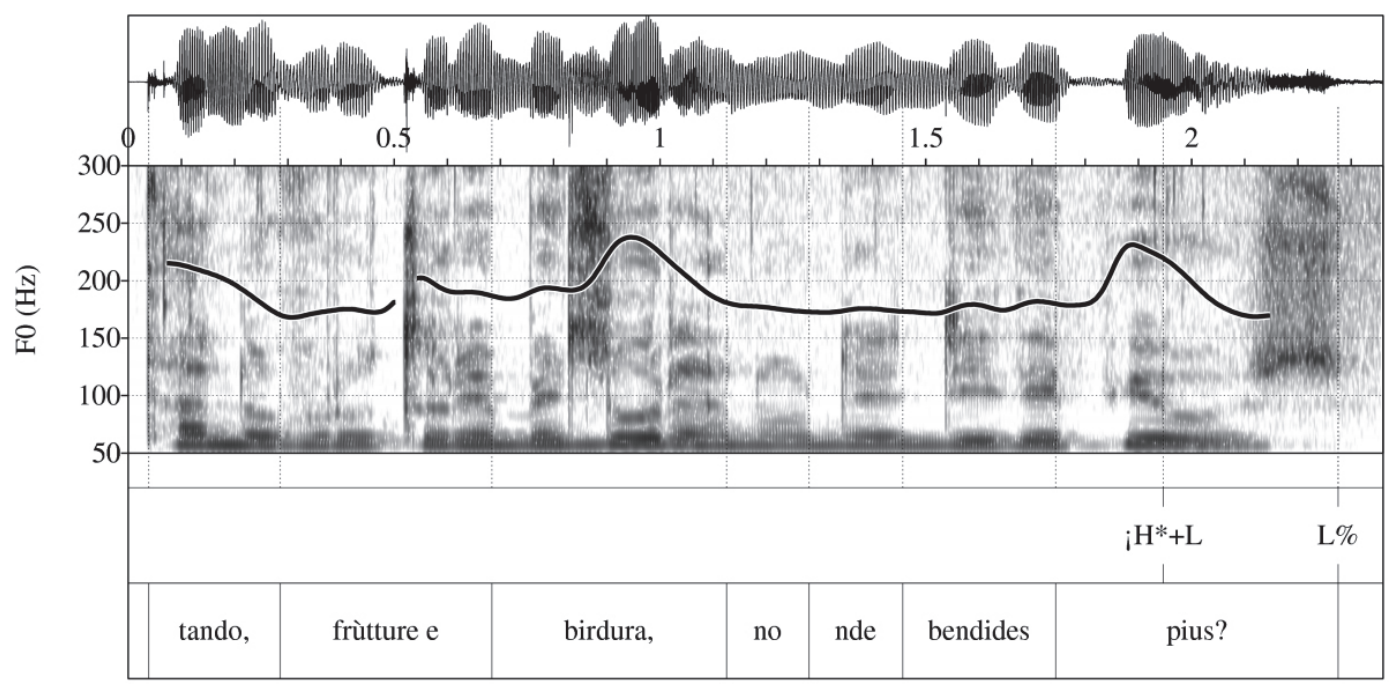

Table 2: Summary of the preferred strategies found in Sardinian polar questions for each BIAS-POLARITY condition.

\begin{tabular}{|c|c|c|}
\hline Bias-Polarity conditions & $1^{\text {st }}$ preferred strategy & $2^{\text {nd }}$ preferred strategy \\
\hline Neutral condition & $\begin{array}{c}a+{ }^{2} \mathrm{H}^{*}+\mathrm{L} \mathrm{L} \% \\
\text { A nde tenes, tumattas? } \\
\text { 'Do you have any, tomatoes?' }\end{array}$ & $\begin{array}{c}a+{ }^{2} \mathrm{H}+\mathrm{L} * \mathrm{~L} \% \\
\text { Una caramella, a l'as? } \\
\text { ‘A cough drop, do you have one?' }\end{array}$ \\
\hline Positive epistemic condition & $\begin{array}{c}\text { fronting }+{ }_{i} \mathrm{H}^{*}+\mathrm{L} \mathrm{L} \% \\
\text { Battidas mi las as, sas caramellas? } \\
\text { 'Have you brought them to me, the cough } \\
\text { drops?' }\end{array}$ & $\begin{array}{l}\text { neutral wo }+{ }_{j} \mathrm{H}^{*}+\mathrm{L} \mathrm{L} \% \\
\text { Mi l'as battidu, su liberu? } \\
\text { 'Have you brought it to me, the book?' }\end{array}$ \\
\hline Negative epistemic condition & $\begin{array}{c}\text { fronting }+{ }_{i} \mathrm{H}^{*}+\mathrm{L} \mathrm{L} \% \\
\text { Battidu mi l'as, su liberu? } \\
\text { 'Have you brought it to me, the book?' }\end{array}$ & $\begin{array}{l}\text { neutral wo }+{ }_{i} \mathrm{H}^{*}+\mathrm{L} \mathrm{L} \% \\
\text { Mi l'as battidu, su liberu? } \\
\text { 'Have you brought it to me, the book?' }\end{array}$ \\
\hline Positive evidential condition & $\begin{array}{l}\text { fronting }+{ }_{i} \mathrm{H}^{*}+\mathrm{L} \mathrm{L} \% \\
\text { Ma in pitzione ses andada? } \\
\text { 'Have you retired?' }\end{array}$ & $\begin{array}{c}\text { neutral wo }+\mathrm{¡H}^{*}+\mathrm{L} \mathrm{L} \% \\
\text { Ma fiza tua, pro casu est diventada } \\
\text { professoressa? } \\
\text { 'By any chance has your daughter become } \\
\text { a teacher?' }\end{array}$ \\
\hline Negative evidential condition & $\begin{array}{l}\text { negation }+{ }_{i} \mathrm{H}^{*}+\mathrm{L} \mathrm{L} \% \\
\text { Tando, frùtture e birdura, no nde bendides } \\
\text { pius? } \\
\text { 'So, fruit and vegetables, you aren't going to } \\
\text { sell them anymore?' }\end{array}$ & $\begin{array}{l}\text { negation }+{ }_{i} \mathrm{H}+\mathrm{L} * \mathrm{~L} \% \\
\text { Non ti l'ant a rinnovare, su cuntrattu? } \\
\text { 'They will not renew it, the contract?' }\end{array}$ \\
\hline
\end{tabular}


tance with the $¡ \mathrm{H}+\mathrm{L} * \mathrm{~L} \%$ (see the Discussion section below).

A series of Wilcoxon matched pairs signed rank tests revealed statistical differences only between the positive evidential condition and the neutral condition $(T=36, p<$ $.05, r=-.18)$ for LEXICO-SYNTACTIC STRATEGY. Regarding the negative evidential condition, no significant statistical differences were found between any conditions for either INTONATION Or LEXICO-SYNTACTIC STRATEGY.

Figure 12 shows an example of a polar question with constituent fronting and the $\mathrm{iH}^{*}+\mathrm{L} \mathrm{L} \%$ intonational pattern produced in the positive evidential condition. Figure 13 illustrates a polar question with negation and again the ${ }_{i} \mathrm{H}^{*}+\mathrm{L} \mathrm{L} \%$ intonation produced in a negative evidential condition.

Finally, Table 2 offers a summary of the preferred strategies, lexico-syntactic and intonational, for each BIAS-POLARITY condition.

\section{DISCUSSION}

This study set out to refine the analysis presented in Vanrell, Ballone, et al. (2014, in press) for the ${ }_{i} \mathrm{H}+\mathrm{L} * \mathrm{~L} \%$ and ${ }_{i} \mathrm{H}^{*}+\mathrm{L} \mathrm{L} \%$ nuclear configurations associated with unbiased and biased polar questions respectively. We also wanted to assess whether the correspondence between lexico-syntactic and intonational structure proposed in Contini (1984) and Vanrell et al. (in press) was supported by our data. Finally, we sought to provide some sort of explanation for the distribution of the different linguistic markers found in Sardinian polar questions. To this end, a production experiment was designed aiming to elicit polar questions with different bias and polarity conditions by means of the DCT methodology. The collected data were prosodically and syntactically annotated and then analyzed.

The results show a clear preference for the particle $a$ in the neutral condition (e.g., $\boldsymbol{A}$ nde tenes, tumattas? 'Do you have any, tomatoes?'), but two different intonational patterns can be found with this lexico-syntactic strategy: the ${ }_{i} \mathrm{H}+\mathrm{L}^{*} \mathrm{~L} \%$ pattern (see Figure 4) and the ${ }_{j} \mathrm{H}^{*}+\mathrm{L} \mathrm{L} \%$ pattern (see Figure 5). If we take a closer look at the data, we realize that most of the $i \mathrm{H}^{*}+\mathrm{L} \mathrm{L} \%$ tokens were produced in the pragmatic situation in which the speaker meets a friend and while they are talking the speaker realizes that it might be possible for her to offer tomatoes to her friend, since she has plenty of them at home. The question was supposed to determine whether the interlocutor already had tomatoes (and therefore would not need any more), but the speaker could also be simply offering tomatoes. According to Jones (1993) and as also noted in the Introduction, the particle $a$ can be related to questions which are to be interpreted as requests, invitations and offers, as well as to true polar questions. In addition, offers in Algherese (a Catalan variety spoken in northern Sardinia which exists in close contact with Logudorese Sardinian) can be headed by the particle $a$ and tend to present the $\mathrm{iH}^{*}+\mathrm{L} \mathrm{L} \%$ pattern described above (e.g., $\boldsymbol{A}$ véns amb mi que te convid calqui cosa? 'Do you want to come with me and I'll buy you something?'; Vanrell, Roseano, \& Cabré, 2013, p. 167). Interestingly, the particle $a$ comes from the Latin aut 'or' which has an exclusive character compared to vel 'or', which had an inclusive meaning (Remberger, 2010, p. 570). According to Remberger (2010), this particle in origin was a former exclusive alternative operator similar to the Polish interrogative particle $c z y$. A tentative hypothesis could be that the particle $a$ is a politeness marker (already proposed by Jones, 1993) that mitigates the request for information in the case of true polar questions and conveys the speaker's willingness to accept denial or acceptance in offers. That would explain why this particle fits well in both contexts, a neutral context and that of an offer/invitation. ${ }^{7}$ As for intonation, the ${ }_{i} \mathrm{H}+\mathrm{L} * \mathrm{~L} \%$ pattern (see Figure 4 ) could be marking "lack of bias" (we will explain later why it can appear in contexts with negative bias). On the other hand, the ${ }_{i} \mathrm{H}^{*}+\mathrm{L} \mathrm{L} \%$ pattern (see Figure 5) would be used to express bias based on beliefs, expectations, word knowledge or information that has become available in the discourse context. In the case of offers expressed through the combination of the particle $a$ and the pattern $\mathrm{H}^{*}+\mathrm{L}$, the speaker would leave the door open to either an affirmative or negative response on the part of the interlocutor, while expressing his/her obliging disposition. It could be paraphrased as something like "You are free to accept or reject my proposal, but I want to let you know that I would like you to accept". The use of the ${ } \mathrm{H}^{*}+\mathrm{L} \mathrm{L} \%$ pattern as an invitation/offer agrees with Armstrong (in press). In her study about polar questions in Puerto Rican Spanish, she finds that $\mathrm{H}+\mathrm{L}^{*} \mathrm{~L} \%$ encodes positive epistemic bias but is also felicitous in the context of an offer/ invitation. According to the author, by using this intonational pattern, the speaker can express his/her desire for the hearer to accept the invitation. This would not be problematic with the fact that $\mathrm{H}+\mathrm{L} * \mathrm{~L} \%$ in Puerto Rican Spanish encodes positive bias (as it is also the case for ${ }_{i} \mathrm{H}^{*}+\mathrm{L} \mathrm{L} \%$ in Logudorese Sardinian), because the definition of epistemic bias in Sudo (2013) includes both beliefs and desires (Armstrong, in press).

The preferred pattern in the epistemic conditions is the ${ }_{i} \mathrm{H}^{*}+\mathrm{L} \mathrm{L} \%$ intonation produced on a polar question

\footnotetext{
${ }^{7}$ According to personal communication with Wojtek Lewandowski, the interrogative particle $c z y$ could also be functioning as a mitigator in the following questions:

(1) Czy można się dosiąść? 'Can we sit down?'

(2) Czy można tu palić? 'Can I smoke here?'
} 
with constituent fronting (e.g., Custu liberu, dae munitzipiu, battidu mi l'as? 'Regarding the book from the city council, have you brought it to me?'). Another possible strategy, especially in the negative epistemic condition, is the ${ }_{i} \mathrm{H}^{*}+\mathrm{L} \mathrm{L} \%$ pattern, this time realized on a polar question with neutral word order (e.g., Mi l'as battidu, su liberu? 'Have you brought it to me, the book?'). In the neutral condition, we interpreted the ${ }_{i} \mathrm{H}^{*}+\mathrm{L}$ L\% pattern as a carrier of "bias". Now we add the notion of "positive", that is, leading to a positive response, conveyed by the constituent fronting. This idea is reinforced by the fact that in negative epistemic contexts, we find a slight decrease in constituent fronting (17/23 vs. 15/26 which means $73 \%$ vs. $57 \%$ of the total data). This is correlated with an increase in the number of questions with neutral word order (Figure 7).

In the evidential condition two different patterns are found depending on the polarity of the bias condition, that is, whether the question conveys the speaker's bias towards a positive or negative answer. When the speaker's bias is towards an affirmative response, as expected, the preferred strategy is the $\mathrm{iH}^{*}+\mathrm{L} \mathrm{L} \%$ in combination with constituent fronting (e.g., Ma in pintzione ses anda$d a$ ? 'Have you retired?'). However, when the speaker's bias leans towards a negative response, we find a negative polar question (Ma no nde bendides pius, de frùtture e de birdura, como? 'You will not sell them anymore, fruit and vegetables?') with either the ${ } \mathrm{H}^{*}+\mathrm{L} \mathrm{L} \%$ (Figure 13) or the ${ }_{\mathrm{i}} \mathrm{H}+\mathrm{L} * \mathrm{~L} \%$ intonation. The appreciable number of questions with $¡ \mathrm{H}+\mathrm{L} * \mathrm{~L} \%$ intonation (5 out of 19 polar questions) produced in the negative evidential condition could be explained, as kindly suggested by a reviewer, by the fact that all the contexts we used to elicit polar questions in this condition were contexts in which the speakers might be surprised (the speaker was always getting bad news; someone might be fired or a shop was about to close). One could hypothesize, then, that this contour can also be used to convey surprise in this language variety. In any case, this is only a conjecture and perceptual evidence would be needed to prove that this is the case.

Table 3 offers a summary of the lexico-syntactic and intonational linguistic markers found in our data as well as their associated meaning. Our data allow us to disentangle the specific contribution of the particle $a$ to polar questions. Up to now this particle had been characterized as an encoder of positive polarity (with no clear difference relative to focus fronting; Remberger, 2010), as a particle heading requests, invitations and offers (Jones, 1993) or as having the function of assigning "focal value to the content in its scope" (Floricic, 2009). Our own interpretation, however, is that the particle $a$ is a mitigator or politeness marker that mitigates the request for information in neutral polar questions or gives the hearer the possibility of accepting or refusing the invitation in offers. Our proposal is based on two observations derived from our data. The first one is that this particle does not appear in pragmatic contexts other than neutral. This indicates that the meaning of this particle cannot be associated with speaker bias, otherwise it might be felicitous in a
Table 3: Summary of the different linguistic markers found in Sardinian polar questions and their associated meanings.

\begin{tabular}{|l|l|}
\hline \multicolumn{1}{|c|}{ Linguistic markers } & \multicolumn{1}{|c|}{ Meaning } \\
\hline $\begin{array}{l}\text { particle } a \\
\text { (e.g., Una caramella, a l'as? } \\
\text { 'A cough drop, do you have } \\
\text { one?') }\end{array}$ & $\begin{array}{l}\text { politeness marker / } \\
\text { mitigator-willingness to } \\
\text { accept denial or acceptance, } \\
\text { mitigating the request for } \\
\text { information }\end{array}$ \\
\hline $\begin{array}{l}\text { constituent fronting } \\
\text { (e.g., Battidas mi las as, } \\
\text { sas caramellas? 'Have you } \\
\text { brought them to me, the } \\
\text { cough drops?') }\end{array}$ & positive bias \\
\hline $\begin{array}{l}\text { negation } \\
\text { (e.g., Non ti l'ant a } \\
\text { rinnovare, su cuntrattu? } \\
\text { 'They will not renew it for } \\
\text { you,the contract?') }\end{array}$ & negative bias \\
\hline ¡H+L* L\% & lack of bias \\
\hline ¡H*+L L\% & bias \\
\hline
\end{tabular}

situation where the speaker has epistemic or evidential bias leaning towards an affirmative response. The second observation is that it is not the particle alone which is responsible for the conveyance of offers or invitations, but rather the combination of the particle with the $\mathrm{iH}^{*}+\mathrm{L} \mathrm{L} \%$ intonation.

With respect to constituent fronting, our results agree with the proposal in Remberger (2010). Thus, it encodes "positive focus" in terms of Remberger or that the speaker expects it to be true that $p$ (Remberger, 2010, p. 571). This explains why constituent fronting is very residual (only two cases) in neutral contexts or contexts in which the speaker has no bias. More evidence in favor of "positive bias" as the meaning associated with constituent fronting is provided by the fact that this strategy is incompatible with negation (see Floricic, 2009; Remberger, 2010).

Whereas constituent fronting is related to positive bias, negation and neutral word order (no fronted constituent) seem to be clearly related to negative bias, as we observe a significant increase in the use of this strategy especially in the negative evidential context.

As for intonation, the present data allow us to refine the analysis presented in Vanrell, Ballone, et al. (2014, in press). In those studies, the ${ }_{i} \mathrm{H}+\mathrm{L} * \mathrm{~L} \%$ pattern was related to unbiased polar questions (called also informationseeking yes-no questions in Vanrell et al., in press), whereas the ${ }_{i} \mathrm{H}^{*}+\mathrm{L} \mathrm{L} \%$ pattern was related to biased polar questions (confirmation or echo polar questions in Vanrell et al., in press). We propose now that the ${ }_{i} \mathrm{H}+\mathrm{L} *$ L\% pattern is a marker of "lack of bias". Given that this pattern could also be produced in negative evidential situations, we hypothesize that it can also be used to convey surprise. Further research is required to provide evidence in favor of this hypothesis. The $i^{*}+\mathrm{L} L \%$ pattern remains associated with the speaker's bias either towards an affirmative (in conjunction with constituent fronting) 
or a negative (with negation) response. In offers or invitations, the particle $a$ acts as a politeness marker, avoiding imposition, whereas the ${ }_{i} \mathrm{H}^{*}+\mathrm{L} \mathrm{L} \%$ contour would be related to a certain predisposition to acceptance.

The first stated objective of this paper was to offer a more refined analysis than what is presented in Vanrell, Ballone, et al., (2014, in press) for the ${ }_{i} \mathrm{H}+\mathrm{L} * \mathrm{~L} \%$ and the ${ }_{i} \mathrm{H}^{*}+\mathrm{L} \mathrm{L} \%$ associated with polar questions. This objective has been achieved by proposing the interpretation of "lack of bias" for the ${ }_{i} \mathrm{H}+\mathrm{L} * \mathrm{~L} \%$ intonation, compared to ${ }_{i} \mathrm{H}^{*}+\mathrm{L} \mathrm{L} \%$, which is associated with the expression of speaker bias. ${ }_{i} \mathrm{H}+\mathrm{L}^{*} \mathrm{~L} \%$ could also be related to surprise, specifically, to negative surprise caused by getting bad news. With respect to the second goal, which was to test the assertion that there exists a one-to-one correspondence between lexico-syntactic and intonational structures, we have provided evidence against the idea that the intonational form in Sardinian polar questions is determined by the lexico-syntactic structure. By contrast, what we see is that the same lexico-syntactic structure can bear different contours and that it is the combination of a particular lexico-syntactic form with a contour that determines the meaning of the utterance. This has typological implications in that it demonstrates that (a) languages can employ a combination of intonation and other mechanisms (such as question particles or changes in word order) to mark polar questions and (b) the use of these mechanisms can be with the expression of not only sentence modality but also a speaker bias towards an affirmative or negative response. Finally, we have provided a tentative pragmatic interpretation of the multiple mechanisms existing in Sardinian to construct polar questions. Further research could be carried out to determine whether the pragmatic analysis provided here also works at the perceptual level.

\section{CONCLUSIONS}

This article has described the intonation patterns of polar questions in Sardinian by considering also its interaction with syntactic structure and the appearance of syntactic particles. We claim that the joint analysis of all these components is needed in order to obtain an integrative view of how prosodic patterns work together with other grammatical components in natural languages. The results demonstrate that the different lexico-syntactic and intonational choices correspond to the expression of speaker bias in yes-no questions. Specifically, we have demonstrated that regarding the lexico-syntactic markers, the particle $a$ acts as a mitigator or politeness marker, whereas constituent fronting and negation correspond to positive and negative bias respectively. With respect to intonation, two different patterns are distinguished, the ${ }_{i} \mathrm{H}^{*}+\mathrm{L} \mathrm{L} \%$ pattern and the ${ }_{i} \mathrm{H}+\mathrm{L} * \mathrm{~L} \%$ pattern, which represent 79 and 22 out of 112 cases respectively. The ${ }_{i} \mathrm{H}+\mathrm{L}^{*}$ $\mathrm{L} \%$ pattern is interpreted as marking "lack of bias". By contrast, the ${ }_{i} \mathrm{H}^{*}+\mathrm{L} \mathrm{L} \%$ pattern is restricted to situations in which the speaker is expressing his/her bias towards an affirmative or negative response. Interestingly, no specific marker was found that distinguishes between epistemic and evidential bias.

\section{ACKNOWLEDGEMENTS}

A preliminary version of this paper was presented at the $V$ Congreso de Fonética Experimental (Cáceres, Spain, 25-28 October, 2011), an invited seminar at the Universität Konstanz-Germany (10 July, 2012), the Sardinian Network Meeting (Konstanz, Germany, 4 September, 2012), the Modality, Corpus, Discourse conference (Lund, Sweden, 7-8 June, 2012) and the Laboratory Approaches to Romance Phonology 6 conference (Mexico City, Mexico, 3-5 October, 2012). We are grateful for all the comments and suggestions received by the audience at these conferences. Antoni Canu and Miquel Canu deserve a special mention for helping us to find participants in Ottieri, and of course we are heavily indebted to all the subjects that participated in the different experiments. The authors would like to thank research assistant AnneKathrin Knecht for help in the preparation of this article and Joan Borràs-Comes for kindly providing us with the map that appears in Figure 1. Meghan E. Armstrong deserves a special acknowledgment for always being ready to discuss the Sardinian data and its possible pragmatic interpretations. Finally, we also owe many thanks to two anonymous reviewers for constructive comments, which helped us to improve the manuscript. This research was funded by projects FFI2011-23829/FILO, BFU201231995 (awarded by the Spanish Ministry of Science and Innovation and the Spanish Ministry of Economy and Competitiveness), and 2009 SGR 701 and 2014 SGR925 (awarded by the Generalitat de Catalunya).

\section{REFERENCES}

Álvarez, A., \& Blondet, M. A. (2003). Cortesía y prosodia: Un estudio de la frase cortés en el español de Mérida. In E. Herrera Z. \& P. M. Butragueño (Eds.), La tonía: Dimensiones fonéticas y fonológicas (pp. 319-330). México D.F.: El Colegio de México.

Armstrong, M. E. (in press). Accounting for intonational form and function in Puerto Rican Spanish polar questions. Probus.

Asher, N., \& Reese, B. (2007). Intonation and discourse: Biased questions. In S. Ishihara, S. Jannedy, \& A. Schwar (Eds.), Interdisciplinary studies on information structure, 8 (pp. 1-38). Potsdam: Universität Potsdam.

Astruc, L., Vanrell, M. M., \& Prieto, P. (in press). Intonational phonology and pragmatics: The intonation of offers in Catalan. In M. E. Armstrong, N. Henriksen, \& M. M. Vanrell (Eds.), Interdisciplinary approaches to intonational grammar in Ibero-Romance. Amsterdam: John Benjamins.

Barron, A. (2003). Acquisition in interlanguage pragmatics: Learning how to do things with words in a study abroad context. Amsterdam: John Benjamins. http://dx.doi.org/10.1075/pbns. 108

Billmyer, K., \& Varghese, M. (2000). Investigating instrumentbased pragmatic variability: Effects of enhancing discourse completion tests. Applied Linguistics, 21(4), 517-552. http:// dx.doi.org/10.1093/applin/21.4.517 
Blum-Kulka, S., House, J., \& Kasper, G. (1989). Investigating cross-cultural pragmatics: An introductory overview. In S. Blum-Kulka, J. House \& G. Kasper (Eds.), Crosscultural pragmatics: Requests and apologies (pp. 1-34). Norwood, NJ: Ablex.

Brandi, L., \& Cordin, P. (1989). Two Italian dialects and the null subject parameter. In O. A. Jaeggli \& K. J. Safir (Eds.), The null subject parameter (pp. 111-142). Dordrecht: Kluwer. http:// dx.doi.org/10.1007/978-94-009-2540-3 4

Büring, D., \& Gunlogson, C. (2000). Aren't positive and negative polar questions the same? Retrieved from http://hdl.handle. net/1802/1432

Comitao Scientificu po sa Norma Campidanesa de su Sardu Standard (2009). Arrègulas po ortografia, fonètica, morfologia e fueddàriu de sa Norma Campidanesa de sa Lingua Sarda. Quartu Sant'Elena: Alfa.

Contini, M. (1984). L'intonation des phrases affirmatives et interrogatives, avec inversion en sarde. Analyse et synthèse. Bulletin de l'Institut de Phonétique de Grenoble, 13, 131-152.

Crespo-Sendra, V. (2011). Aspectes de l'entonació del valencià (Doctoral dissertation). Barcelona: Universitat Pompeu Fabra.

Dol, P. (1999). A Grammar of Maybrat: A language of the Bird's Head, Irian Jaya, Indonesia. Leiden: University of Leiden.

Dryer, M. S. (2013). Polar questions. In M. S. Dryer \& M. Haspelmath (Eds.), The World Atlas of Language Structures Online. Leipzig: Max Planck Institute for Evolutionary Anthropology. Retrieved from http://wals.info/chapter/116.

Estrella-Santos, A. (2007, June). Politeness and prosody: Interaction of prosody in the requests with "dar" as a benefactive in Ecuadorian Andean Spanish. Paper presented at the Phonetics and Phonology in Iberia 2007 Conference (PaPI), Braga.

Everett, D. L. (1986). Pirahã. In D. C. Derbyshire \& G. K. Pullum (Eds.), Handbook of Amazonian languages: Vol. 1 (pp. 200325). Berlin, Germany: Mouton de Gruyter. http://dx.doi. org/10.1515/9783110850819.200

Félix-Brasdefer, J. C. (2010). Data collection methods in speech act performance: DCTs, role plays, and verbal report. In A. Martínez-Flor \& E. Usó-Juan (Eds.), Speech act performance: Theoretical, empirical and methodological issues (pp. 41-56). Amsterdam: John Benjamins. http://dx.doi.org/10.1075/11lt.26.03fel

Floricic, F. (2009). Negation and "Focus Clash" in Sardinian. In L. Mereu (Ed.), Information structure and its interfaces (pp.129152). Berlin: Mouton de Gruyter. http://dx.doi. org/10.1515/9783110213973.2.129

Fossat , J.-L. (2006). Les «petits mots» énonciatifs gascons: Le cas de bè énonciatif. Cahiers de Grammaire, 30, «Spécial Anniversaire», 159-174.

Grice, M., \& Savino, M. (1997). Can pitch accent type convey information-status in yes-no questions? In A. Kai, H. Pirker, \& W. Finkler (Eds.), Proceedings of the ACL/EACL '97 Workshop on Concept-to-Speech Generation Systems (pp. 29-38).

Grice, M., \& Savino, M. (2003). Question type and information structure in Italian. In A. Mettouchi \& G. Ferré (Eds.), Proceedings of Prosodic Interfaces (IP 2003) (pp. 117-122).

Haan, J. (2001). Speaking of questions: An exploration of Dutch question intonation (Doctoral dissertation). Utrecht: LOT.

Haas, Mary R. (1940). Tunica. New York: J. J. Augustin.

Hara, Y. (2013). On the interaction among sentence types, bias, and intonation: A rating study. In Proceedings of GLOW in Asia IX. Retrieved from http://faculty.human.mie-u.ac.jp/ glow_mie/ IX Proceedings Poster/06Hara.pdf

Hara, Y., \& Kawahara, S. (2012). The prosody of public evidence in Japanese: A rating study. In J. Choi, A. Hogue, J. Punske, D. Tat, J. Schertz, \& A. Trueman (Eds.), Proceedings of the 29th West Coast Conference on Formal Linguistics (pp. 353-361). Somerville, MA: Cascadilla Press.

Hayward, R. J. (1990). Notes on the Zayse language. In R. J. Hayward (Ed.), Omotic language studies (pp. 210-355). London: School of Oriental and African Studies.

Hwang, H. K., \& Ito, S. (2014). Correlations between prosody and epistemic bias in negative polar interrogatives in Japanese. Proceedings of Speech Prosody 2014 (pp. 925-928).
Ito, S., \& Oshima, D. Y. (in press). On two varieties of negative polar interrogatives in Japanese. In M. Kenstowicz, T. Levin \& R. Masuda (Eds.), Japanese/Korean Linguistics, CSLI Publications. Retrieved from http://www.gsid.nagoya-u.ac.jp/oshima/ docs/JK23-negative-questions.pdf

Jones, M. A. (1988). Sardinian. In M. Harris \& N. Vincent (Eds.), The Romance languages, (pp. 314-350). New York: Oxford University Press.

Jones, M. A. (1993). Sardinian syntax. New York: Routledge.

Karenova, K. (2006). Théories linguistiques et phénomènes discursifs: Interface complexe en Gascon. Actes de l'Atelier bilingue en linguistique théorique 2005. Proceedings of the 2005 Bilingual Workshop in Theoretical Linguistics. Retrieved from http://westernlinguistics.ca/Publications/BWTL9-ABLT9/ Karenova.pdf

Kügler, F. (2003). Do we know the answer? Variation in yes-no question intonation. In S. Fischer, R. van de Vijver, \& R. Vogel (Eds.), Linguistics in Potsdam, 21, (pp. 9-29). Potsdam: Universitätsbibliothek Publikationsstelle.

Ladd, D. R. (1981). A first look at the semantics and pragmatics of negative questions and tag questions. Proceedings of the Chicago Linguistics Society, 17 (pp. 164-171).

Lee, S. A. (2010). Absolute question intonations in Buenos Aires Spanish (Doctoral dissertation). Columbus: Ohio State University.

Lusini, S. (2013). Yes-no question/marking in Italian dialects: A typological, theoretical and experimental approach (Doctoral thesis). Leiden: Universiteit Leiden.

Manzini, M. R., \& Savoia, L. M. (2005). I dialetti italiani e romanci. Morfosintassi generativa: Vol. I. Alessandria: Edizioni dell'Orso.

Nadeu, M., \& Prieto, P. (2011). Pitch range, gestural information and perceived politeness in Catalan. Journal of Pragmatics, 43(3), 841-854. http://dx.doi.org/10.1016/j.pragma.2010.09.015

Orozco Vaca, L. (2008). Peticiones corteses y factores prosódicos. In E. Herrera Z. \& P. M. Butragueño (Eds.), Fonología instrumental: Patrones fónicos y variación (pp. 335-356). México D.F.: El Colegio de México

Orozco Vaca, L. (2010). Estudio sociolingüístico de la cortesía en tratamientos y peticiones. Datos de Guadalajara (Doctoral dissertation). México D.F.: El Colegio de México.

Poletto, C. (1991). The diachronic development of subject clitics in North Eastern Italian dialects. University of Venice Working Papers in Linguistics, 1, 1-68. Venezia: Università Ca'Foscari Venezia.

Prieto, P., \& Rigau, G. (2007). The syntax-prosody interface: Catalan interrogative sentences headed by que. Journal of Portuguese Linguistics, 6(2), 29-59.

Pusch, C. D. (2000). L'énonciatif gascon entre pragmatique et grammaire: Analyse d'un corpus oral. Actes du XXII Congrès International de Linguistique et de Philologie Romanes, 7 (pp. 625-630)

Regione Autonoma della Sardegna (2006). Limba Sarda Comuna. Normas linguisticas de referèntzia a caràtere isperimentale pro sa limba sarda iscrita de s'Amministratzione regionale. Retrieved from http:// www.sardegnacultura.it/documenti/7_108_20090205122432.pdf

Remberger, E.-M. (2010). Left-peripheral interactions in Sardinian. Lingua, 120(3), 555-581. http://dx.doi.org/10.1016/j. lingua.2008.10.010

Renzi, L., \& Vanelli, L. (1982). I pronomi soggetto in alcune varietà romanze. In Scritti linguistici in onore di Giovan Battista Pellegrini: Vol. 2 (pp. 121-145), Pisa: Pacini.

Rigau, G. (2002). La posición del sujeto en catalán. In J. M. Brañas, C. Nak-Won, \& S. Chan-Yong (Eds.), Conexiones de la sociedad coreana y la española. I Congreso Internacional de Coreanología, (pp. 71-82), Universitat Autonóma de Barcelona/Universidad Nacional de Chonbuk: Publicaciones Digitales.

Rizzi, L. (1986). On the status of subject clitics in Romance. In O. Jaeggli \& C. Silva-Corvalán (Eds.), Studies in Romance linguistics (pp. 391-419). Dordrecht: Foris.

Romero, M., \& Han, C-H. (2002). Verum focus in negative yes/no questions and Ladd's $\mathrm{p} / \neg \mathrm{p}$ ambiguity. In B. Jackson (Ed.), 
Proceedings of Semantics and Linguistic Theory (SALT XII) (pp. 204-223). Ithaca, NY: CLC Publications.

Santos, A. L., \& Mata, A. I. (2008, September). Between form and meaning: Using intonation cues to identify confirmation-seeking requests. Poster presented at the 3rd European Conference on Tone and Intonation (TIE 3), Universidade de Lisboa.

Schirru, C. (1982). Analyse intonative de l'énonciation et de la question totale dans l'italien régional de Cagliari. Bulletin de l'Institut de Phonétique de Grenoble, 10-11, 169-184.

Schirru C. (1992a). Premiers éléments d'analyse prosodique contrastive entre le sarde, l'italien et le français: Résultats statistiques. Travaux de l'Institut de Phonétique d'Aix-en-Provence, $14,77-108$

Schirru, C. (1992b). Etude prosodique contrastive entre le sarde, l'italien et le français. Approche complémentarie. Proceedings of the Federation of Acoustical Society of Europe Congress (pp. 177-180).

Sudo, Y. (2013). Biased polar questions in English and Japanese. In D. Gutzmann \& H.-M. Gärtner (Eds.), Beyond expressives: Explorations in use-conditional meaning (pp. 275-295). Leiden: Brill. http://dx.doi.org/10.1163/9789004183988_009

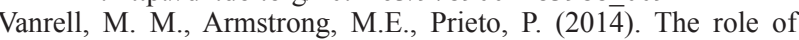
prosody in the encoding of evidentiality in Catalan. Proceedings of Speech Prosody 2014 (pp. 1022-1025).
Vanrell, M. M., Ballone, F., Schirru, C., \& Prieto, P. (2014). Lexicosyntactic and intonational marking of evidential and epistemic bias in Sardinian yes-no questions. In Y. Congosto Martín, M. L. Montero Curiel, \& A. Salvador Plans (Eds.), Fonética experimental, educación superior e investigación: Vol. 3. Prosodia (pp. 541-560). Madrid: Arco/Libros.

Vanrell, M. M., Ballone, F., Schirru, C., \& Prieto, P. (in press). Sardinian intonational phonology: Logudorese and Campidanese varieties. In S. Frota \& P. Prieto (Eds.), Intonational variation in Romance (pp. 317-349). Oxford, UK: Oxford University Press.

Vanrell, M. M., \& Fernández Soriano, O. (2013). Variation at the interfaces in Ibero-Romance. Catalan and Spanish prosody and word order. Catalan Journal of Linguistics, 12, 253-282.

Vanrell, M. M., Fernández-Soriano, O. (2014). Dialectal variation at the prosody-sintax interface: Evidence from Catalan and Spanish interrogatives. Proceedings of Speech Prosody 2014 (pp. 698-701)

Vanrell, M. M., Mascaró, I., Torres-Tamarit, F., Prieto, P. (2013). Intonation as an encoder of speaker certainty: Information and confirmation yes-no questions in Catalan. Language and Speech, 56(2), 163-190. http://dx.doi.org/10.1177/0023830912443942

Vanrell, M. M., Roseano, P., Cabré, T. (2013). Alguerès. In P. Prieto \& T. Cabré (Eds.), L'entonació dels dialectes catalans. Barcelona: L'Abadia de Montserrat. 


\section{APPENDIX}

\begin{tabular}{|c|c|}
\hline \multicolumn{2}{|c|}{ Neutral condition } \\
\hline $\begin{array}{l}\text { Has unu pagu de tusciu e, tott'in una, faeddende cun una } \\
\text { de carrela, incumintzas a intèndere unu iscrafinzu a ula. } \\
\text { Pregunta-li si at una caramella. }\end{array}$ & $\begin{array}{l}\text { 'You have a bit of a cough and suddenly, while you're talking } \\
\text { to a neighbor, you feel a sore throat coming on. Ask her if she } \\
\text { has a cough drop.' }\end{array}$ \\
\hline $\begin{array}{l}\text { Andas a piatta e, in caminu, intopas un'amiga. Faeddende } \\
\text { faeddende, ti benit a conca chi in domo ses piena de tumattas, } \\
\text { e nde li podes dare unu pagu, si nde li servint. Pregunta } \cdot l i \text { si } \\
\text { nd'at, de tumattas. }\end{array}$ & $\begin{array}{l}\text { 'You go to the square and meet a friend. While you're talking to } \\
\text { her, it springs to your mind that you have plenty of tomatoes at } \\
\text { home and that maybe you could offer some of them to her. Ask } \\
\text { her whether she has tomatoes.' }\end{array}$ \\
\hline \multicolumn{2}{|c|}{ Positive epistemic condition } \\
\hline $\begin{array}{l}\text { Una de carrela t'at nadu chi fut andende a sa butica, e } \\
\text { t'at preguntadu si cherias calchi cosa dae in ie. Tue nd'as } \\
\text { aprofittadu, e l'as nadu de ti comporare sas caramellas pro sa } \\
\text { ula, chi ti dolet meda. Cando la bides torrende, li preguntas si } \\
\text { t'at battidu sas caramellas. }\end{array}$ & $\begin{array}{l}\text { 'A neighbor of yours told you that she was going to the } \\
\text { pharmacy and asked whether you needed anything from there. } \\
\text { Happy to take advantage of her offer, you asked her to buy you } \\
\text { some cough drops because you have a sore throat. Now you } \\
\text { see her coming back from the pharmacy. Ask her if she got the } \\
\text { cough drops.' }\end{array}$ \\
\hline $\begin{array}{l}\text { Su Munitzìpiu at fattu unu liberu bellu meda chi contat s'istòria } \\
\text { de sa cheja de Santu Pedru in Vincoli, e l'est dende a s'indonu, } \\
\text { una de carrela tua est andende a si lu leare. Tue li naras de } \\
\text { nde leare unu finas pro te. Pro custu, sende torrada dae su } \\
\text { Munitzìpiu, li preguntas si t'at battidu su liberu. }\end{array}$ & $\begin{array}{l}\text { 'The city council has published a very nice booklet about the } \\
\text { history of the Santu Pedru in Vincoli church and it is being } \\
\text { distributed free of charge. A neighbor of yours goes to the city } \\
\text { council to get one of them and you ask her to pick one up for } \\
\text { you too. When you see her coming back, ask her whether she's } \\
\text { bringing it.' }\end{array}$ \\
\hline \multicolumn{2}{|c|}{ Negative epistemic condition } \\
\hline $\begin{array}{l}\text { Una de carrela t'at nadu chi fut andende a sa butica, e } \\
\text { t'at preguntadu si cherias calchi cosa dae inie. Tue nd'as } \\
\text { aprofittadu, e l'as nadu de ti comporare sas caramellas pro sa } \\
\text { ula, chi ti dolet meda. Su problema est chi a bortas su chi li } \\
\text { naras nche li essit dae conca, li preguntas si non t'at battidu sas } \\
\text { caramellas, pessende chi fossis si nd'est ismentigada. }\end{array}$ & $\begin{array}{l}\text { 'A neighbor of yours told you that she was going to the } \\
\text { pharmacy and asked whether you needed anything from there. } \\
\text { Happy to take advantage of her offer, you asked her to buy you } \\
\text { some cough drops because you have a sore throat. The problem } \\
\text { is that sometimes she forgets things. Now you see her coming } \\
\text { back from the pharmacy. Ask her whether she's bringing them, } \\
\text { presuming that she probably isn't.' }\end{array}$ \\
\hline $\begin{array}{l}\text { Su Munitzìiu at fattu unu liberu bellu meda chi contat s'istòria } \\
\text { de sa cheja de Santu Pedru in Vincoli, e l'est dende a s'indonu, } \\
\text { una de carrela tua est andende a si lu leare. Tue li naras de nde } \\
\text { leare unu finas pro te. Su problema est chi a bortas su chi li } \\
\text { naras nche li essit dae conca. Pro custu, sende torrada dae inie, } \\
\text { li preguntas si non ti nd'at battidu de liberu, pessende chi fossis } \\
\text { si nd'est ismentigada. }\end{array}$ & $\begin{array}{l}\text { 'The city council has published a very nice booklet about the } \\
\text { history of the Santu Pedru in Vincoli church and it is being } \\
\text { distributed free of charge. A neighbor of yours goes to the city } \\
\text { council to get one of them and you ask her to pick one up for } \\
\text { you too. The problem is that sometimes she forgets things. } \\
\text { When you see that she's coming back, ask her whether she's } \\
\text { bringing one for you, presuming that she probably isn't.' }\end{array}$ \\
\hline \multicolumn{2}{|c|}{ Positive evidential condition } \\
\hline $\begin{array}{l}\text { Sorrastra tua torrat in bidda a poi de tantos annos, e ti narat chi } \\
\text { como chi no est tribagliende pius at tempus meda pro fàghere } \\
\text { àtteras cosas. Tue pensas chi custu cheret nàrrere chi est andada } \\
\text { in pintzione, però non ses segura e bi lu preguntas. }\end{array}$ & $\begin{array}{l}\text { 'Your cousin comes back to your village after many years and } \\
\text { tells you that since she's not working anymore, she has more } \\
\text { time to do other things. You think that that means that she's } \\
\text { retired, but you're not sure and ask her.' }\end{array}$ \\
\hline $\begin{array}{l}\text { In carrela intopas un' amiga chi non bidias dae meda. Li } \\
\text { preguntas comente istat sa fiza, e issa ti narat chi est semper } \\
\text { istracca, ca andat semper a s'iscola chitto, a sas otto de } \\
\text { manzanu, battor dies a sa chida. Pro cussu tue li preguntas si sa } \\
\text { fiza est diventada professora. }\end{array}$ & $\begin{array}{l}\text { 'In the street you run into a friend who you haven't seen for a } \\
\text { long time. You ask her how her adult daughter is doing and she } \\
\text { tells you that her daughter is always tired because she starts } \\
\text { school at } 8 \text { A.M. four days a week. For that reason you ask her } \\
\text { whether her daughter has become a teacher.' }\end{array}$ \\
\hline \multicolumn{2}{|c|}{ Negative evidential condition } \\
\hline $\begin{array}{l}\text { Andas a domo e b'acattas a fiza tua. Est bènnida a ti nàrrere chi } \\
\text { s'azienda inue tribagliat at problemas de dinari e tando issa at a } \\
\text { lassare su tribagliu in su mese chi benit. Li preguntas si no l'ant } \\
\text { a rinnovare su cuntrattu. }\end{array}$ & $\begin{array}{l}\text { 'You come back home and find your daughter. She has come } \\
\text { to tell you that her company is having financial difficulties and } \\
\text { that she's going to stop working there next month. Ask her if } \\
\text { she isn't going to be rehired.' }\end{array}$ \\
\hline $\begin{array}{l}\text { Andas a sa buttega in ue ses fittiana, e intendes sos padronos } \\
\text { nende chi cherent incomintzare a cambiare su màndigu friscu } \\
\text { cun cosa cungelada. Tando li preguntas si no ant a bèndere pius } \\
\text { fruttora e birdura. }\end{array}$ & $\begin{array}{l}\text { 'You go to the store you always go to and hear the owners } \\
\text { talking about replacing all the fresh food for frozen products. } \\
\text { Ask them if they're not going to sell fruit and vegetables } \\
\text { anymore.' }\end{array}$ \\
\hline
\end{tabular}

